\title{
Genetic impact on protein content and hullability of sunflower seeds, and on the quality of sunflower meal
}

\author{
Sylvie Dauguet ${ }^{1, \star}$, Françoise Labalette $^{2}$, Frédéric Fine ${ }^{1}$, Patrick Carré ${ }^{3}$, André Merrien $^{4}$ \\ and Jean-Pierre Palleau ${ }^{5}$ \\ 1 Terres Inovia, 11 rue Monge, 33600 Pessac, France \\ 2 Terres Univia, 11 rue de Monceau, CS 60003, 75378 Paris, France \\ 3 OLEAD, 11 rue Monge, 33600 Pessac, France \\ 4 Terres Inovia, 11 rue de Monceau, CS 60003, 75378 Paris, France \\ 5 Terres Inovia, Domaine du Magneraud, 17700 Saint Pierre d'Amilly, France
}

Received 22 December 2015 - Accepted 13 January 2016

\begin{abstract}
Sunflower seed quality, in particular the characteristics of hullability and protein content, has a significant impact on the protein content of the resulting meal. Seeds dehulled before crushing produce a meal with a protein content of approximately 36\%; without dehulling, the protein content is typically in the range of $27-29 \%$. This study seeks to assess the effect of sunflower variety on hullability and protein content. Genetic effects were studied by means of seed samples obtained from a network of variety evaluation trials undertaken across the production area in France for sunflowers. For both characteristics, significant differences between cultivars were observed; as a consequence, the potential protein content of their dehulled meals also ranged widely (34-44\%). Genetic selection, which provides substantial improvements in both oil content and fatty acid composition, should therefore be expected to enhance the quality of sunflower meal.
\end{abstract}

Keywords: Sunflower / hullability / protein / variety

Résumé - Impact de la génétique sur la teneur en protéines et l'aptitude au décorticage des graines de tournesol et sur la qualité du tourteau de tournesol. Le décorticage des graines de tournesol, précédant la trituration, permet d'augmenter la teneur en protéines dans le tourteau jusqu'à $36 \%$ sur matière brute, alors qu'un tourteau obtenu sans décorticage contient 27-29\% de protéines. La qualité des graines de tournesol impacte directement la possibilité d'obtenir un tourteau riche en protéines. Le but de cette étude était d'observer l'effet variétal sur la teneur en protéines et l'aptitude au décorticage des graines de tournesol. Nous avons étudié les effets génétiques avec des échantillons provenant d'un réseau d'essais d'évaluation variétale répartis sur l'aire de production du tournesol en France. Des différences variétales sont significatives pour les deux caractéristiques étudiées. Selon nos résultats, la teneur en protéines calculée dans les tourteaux décortiqués, à partir des caractéristiques mesurées sur les différentes variétés étudiées, varie dans une gamme de 34 à 44\% sur matière brute. La sélection génétique, qui a permis de grandes améliorations sur la teneur en huile et sa composition en acides gras, pourrait dès lors également contribuer à améliorer la qualité protéique du tournesol.

Mots clés : Tournesol / aptitude au décorticage / protéines / variété

\section{Introduction}

Sunflower seed processing produces two principal coproducts: oil, mainly for human consumption, and meal, for animal feed. Two main variants exist in the crushing industry: oil extraction from whole seeds and oil ex-

\footnotetext{
^ Correspondence: s.dauguet@terresinovia.fr
}

traction from partially dehulled seeds. In the first process, the resulting meal is of low protein content (27-29\%). In the second process, the resulting meal has a higher protein content (36\% protein content is a standard quality for this type of meal) and reduced fibre. The second process is highly developed in Eastern Europe and Argentina. In France, until recently, dehulling was carried out in only one oil mill which has a limited dehulling capacity offering only a modest improvement 
in meal protein content. Capacity has begun to develop since 2013, with a larger factory now partially dehulling prior to crushing.

Dehulling offers 2 advantages:

- The higher protein and lower fibre content meal has an increased economic value on the animal feed market. Peyronnet et al. (2012) demonstrated that the interest price of a $36 \%$ protein content meal (i.e., that maximum price at which it remained competitive) was $70 \%$ of the soybean meal price, whereas for a $29 \%$ protein meal it was only $43 \%$.

- The hulls removed can be used as an energy source for steam production in a high-performance biomass boiler. Rising energy costs and environmental concerns have led to a growing interest within the crushing industry for using hulls as energy source instead of fossil fuels (Tostain et al., 2012).

In the 1980s, energy prices were very high; towards the end of the decade and the early 1990s, research was undertaken in France to prepare the crushing industry for greater use of the dehulling process. Genetic studies were carried out concerning the ease with which hulls could be removed from sunflower seeds (hullability). These studies showed that this characteristic could be introduced through breeding programmes. Cultivars producing seeds with a smaller hull mass, higher oil content but a good hullability offered the most promise for improving the quality of sunflower meal. Such genotypes were rare, but a recurrent selection programme could be used to increase the frequency of favourable genes (Denis and Vear, 1996). Although all this work constituted a favourable basis for the growth of sunflower dehulling in the French crushing industry, the technology was not developed. In France, the oil mill that only recently reintroduced dehulling actually abandoned the technique in the early 1990s, the context being one where the oil content of the new cultivars was improving but hullability was decreasing, resulting in considerable losses of oil from the hull fraction. At that time moreover, boiler technology for burning hulls had not achieved an adequate level of efficiency. So, the economics were against dehulling. As a consequence, sunflower breeding has ignored the characteristic of hullability, and likewise protein content.

The supply of vegetable protein to livestock is now a matter of political concern. Oilseed meals are an attractive source of proteins. Moreover, sunflowers have the advantage of containing no anti-nutrients or toxic components. Increasing the protein content in sunflower meal would therefore be advantageous. The quality of seeds, notably the protein content expressed as a percentage of Defatted Dry Matter (DDM) and their hullability, determines the potential protein content of the resulting meal. It has been shown that the most profitable way to reach a set requirement of protein content in the meal is to produce seeds with high protein content as a percentage of DDM, in order to require extraction of only a minimum amount of hulls (Dauguet et al., 2015).

The economic focus remains on sunflower oil (about 700 $800 € / \mathrm{t}$ in 2015 , as compared with approximately $180-200 € / \mathrm{t}$ for non-dehulled meal and $250-280 € / t$ for $36 \%$ protein meal). Hence, breeding has always been centred on obtaining varieties combining high yield and high oil content. These are the two criteria that are currently taken into account in the registration of new sunflower varieties; protein content is not a criterion in the registration of new sunflower varieties and nor is it measured in the official trials. Studies have shown that soil and climatic conditions exert a greater influence on protein content than genetics (Dauguet et al., 2015; Nel, 2001; Oraki et al., 2011). This can be explained by the fact that breeding programmes have not searched for variability in protein content. No relationship has been observed between oil content and protein content as a percentage of DDM (Dauguet et al., 2015). So, the independence of these 2 features would suggest that there is considerable scope for improving the protein content of the defatted fraction without penalizing oil content.

Hullability increases with the size of seed and decreases with their oil content; these are varietal characteristics and so genetic improvements of hullability might be considered (Baldini et al., 1994; Dauguet et al., 2015; Denis et al., 1994; Evrard et al., 1996; Nel, 2001; Sharma et al., 2009).

In a previous study (Dauguet et al., 2015), we examined seed samples taken from a wide network of farmers' fields in South West France, looking at 3 varieties, over 2 years (2 varieties each year). Both protein content and hullability were found to be influenced by the environment, with water stress having a substantial effect. Some differences between cultivars could be identified, affecting protein content and hullability. In contrast, the influence of agricultural practices such as nitrogen fertilization could not be established. In order to improve meal quality, and the competitiveness of sunflowers in the food chain, boosting the protein content of sunflower seeds through breeding would be very beneficial, so long as there was no negative effect on oil content and hullability remained adequate.

The objective of the present study, designed in close collaboration with Terres Univia, the French oil and protein crops inter-branch organization, was to improve knowledge of the sunflower cultivars traded on the French market, in particular with regard to their characteristics that impact the possibility of producing good quality meal: seed protein content as a percentage of DDM and hullability. We studied genetic and climatic effects on these characteristics, with samples from a network of varietal evaluation trials, during two consecutive years to evaluate the variability in of marketed sunflower varieties for these or other characteristics not taken into account in breeding programmes. We also measured crude fibre content in order to study its correlation with hullability, and the possibility of evaluating hullability using this more simple analytical result rather than employing laboratory dehulling equipment.

\section{Materials and methods}

\subsection{Samples}

Seed samples were collected from the Terres Inovia experimental network. This is constructed each year to evaluate the performance of varieties marketed in France (agronomic performance such as yield and diseases resistance; quality traits of the seeds such as oil content and Thousand Seed Weight). For the purposes of this study, additional analyses were performed on the seed samples to measure their protein content, hullability and crude fibre content. The varieties studied 
Table 1. Cultivar distribution according to year and locations.

\begin{tabular}{|c|c|c|c|}
\hline Year & Maturity group & $\begin{array}{l}\text { Trial locations (postal code of French } \\
\text { department) }\end{array}$ & Cultivars \\
\hline \multirow{4}{*}{2012} & \multirow[b]{2}{*}{ Early } & $\begin{array}{l}\text { Antoigné (79), Frozes (86), Levroux } \\
\text { (36), Saint Branchs (37), Rhodon (41), } \\
\text { Maslacq (64) }\end{array}$ & $\begin{array}{l}\text { ES Biba, Vellox, Extrasol, ES Balistic, ES } \\
\text { Ethic }\end{array}$ \\
\hline & & Saint-Martial (16), Vibrac (17) & $\begin{array}{l}\text { ES Biba, Vellox, Extrasol, ES Balistic, ES } \\
\text { Ethic, Ullys, Fydgi, Volltage, ES Violetta, } \\
\text { P64LL41, ES Atletic, SY Valeo }\end{array}$ \\
\hline & \multirow[b]{2}{*}{$\mathrm{ME} / \mathrm{ML}$} & $\begin{array}{l}\text { Virson (17), Loudun (86), Vicq/Nahon } \\
\text { (36), Lévignac (31), Tané (32), Le } \\
\text { Saumont (47) }\end{array}$ & $\begin{array}{l}\text { NK Kondi, Kapllan, Extrasol, DKF3333, } \\
\text { LG5656HO }\end{array}$ \\
\hline & & Vibrac (17), Duras (47) & $\begin{array}{l}\text { NK Kondi, Kapllan, Extrasol, DKF3333, } \\
\text { LG5656HO, Breha, Sherllok, Dougllas, } \\
\text { Mobill, SY Edenis, ES Akustic, NK } \\
\text { Adagio, LG5625, ES Tektonic, ES Unic }\end{array}$ \\
\hline \multirow{4}{*}{2013} & & $\begin{array}{l}\text { Vibrac (17), Levroux (36), Meung sur } \\
\text { Loire (45), Ivoy le pré (18), Maslacq (64) }\end{array}$ & $\begin{array}{l}\text { ES Biba, Vellox, Extrasol, SY Valeo, ES } \\
\text { Violetta, Fydgi }\end{array}$ \\
\hline & Early & Antoigné (79), Triaize (85), Trouy (18) & $\begin{array}{l}\text { ES Biba, Vellox, Extrasol, SY Valeo, ES } \\
\text { Violetta, Fydgi, SY Sanbala, P63LL78, } \\
\text { LG5377, Bering, MAS83R, ES Lumina, } \\
\text { ES Columbella, SY Revelio, ES Atletic, } \\
\text { ES Balistic }\end{array}$ \\
\hline & \multirow[b]{2}{*}{$\mathrm{ME} / \mathrm{ML}$} & $\begin{array}{l}\text { Antoigné (79), Benet (85), Lévignac (31), } \\
\text { L'Isle Jourdain (32), Montagnac Auvi- } \\
\text { gnon (47) }\end{array}$ & $\begin{array}{l}\text { NK Kondi, Kapllan, Extrasol, DKF3333, } \\
\text { LG5656HO, Dougllas, ES Tektonic }\end{array}$ \\
\hline & & Pompertuzat (31), Tané (32), Duras (47) & $\begin{array}{l}\text { NK Kondi, Kapllan, Extrasol, DKF3333, } \\
\text { LG5656HO, Dougllas, ES Tektonic, } \\
\text { Clloser, Meddia CS, LG5687HO, SY Ex- } \\
\text { plorer, LG5528, SY Edenis, ES Akustic, } \\
\text { LG5625 }\end{array}$ \\
\hline
\end{tabular}

$\mathrm{ME} / \mathrm{ML}=$ Medium early/medium late.

were oleic and linoleic types in two maturity groups (early or medium early/medium late). Each year, the Terres Inovia experimental network includes about 30 variety trials for each maturity group.

The seed samples collected for this study came from 2012 and 2013. Each year, we collected samples from several experimental locations, from regions where sunflowers are commonly cultivated: South-West, West and Central France (Fig. 1).

Each year, we studied the protein content of 5 to 7 different varieties in each maturity group, in the 8 different trial locations. For hullability and crude fibre analyses, the number of varieties studied was reduced to 2 per maturity group, as the measurements were time-consuming and costly.

In order to investigate the variability of profiles for protein content and hullability, we also studied each year a larger number of varieties (12 and 16) in only 2 or 3 trials (Tab. 1).

Overall, the data set included 275 samples of sunflower seeds, with 40 different sunflower varieties, at 23 different locations (Tab. 1).

\subsection{Chemical analyses}

For each seed sample collected, the oil content was assessed by Nuclear Magnetic Resonance (NF EN ISO 10565)

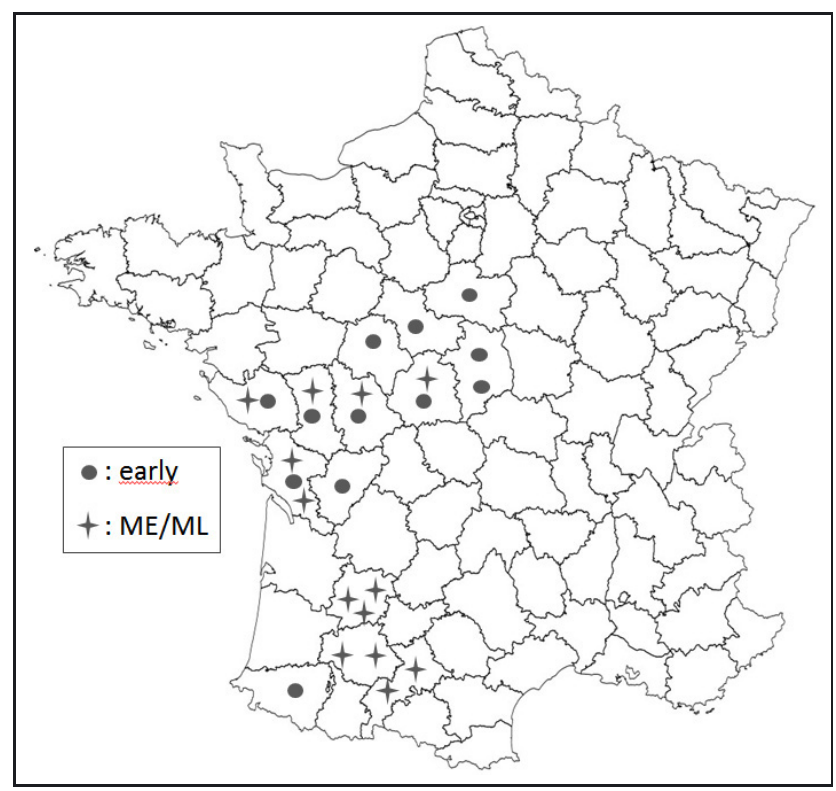

Fig. 1. Location in France of the selected sunflower variety trials in 2012 and 2013, by maturity group.

and expressed as a percentage at marketing standard (9\% moisture content and $2 \%$ impurities level), as commonly used in 
varietal trials. Protein content was assessed by the Dumas method (NF EN ISO 16634-1) and expressed as a percentage of Defatted Dry Matter (DDM) or Dry Matter (DM). The crude fibre content was measured by the Weende method (NF V03040 with previous oil extraction by hexane), and was expressed as a percentage of DDM or DM. The expression of results as a percentage of DDM, for protein or crude fibre content, has an obvious interest from an end-user perspective, as it gives information on the content that would be obtained in the meal, after oil extraction.

An indicator of the seed size, the Thousand seeds weight (TSW), was measured on clean dry grain ( $0 \%$ moisture).

While each sample was analysed for its oil and protein content and TSW, the crude fibre content was assessed in only 2 varieties in each maturity group each year.

All of these analyses were carried out at Terres Inovia's Analysis Laboratory in Ardon.

\subsection{Hullability determination}

What we refer to as "hullability" was obtained by measuring the initial weight of the seeds and the weight of extracted hulls, removed by a standard procedure: Hullability $(\%)=($ mass of extracted hulls $(\mathrm{g})) /($ mass of initial seeds $(\mathrm{g}))$.

Seed hullability is affected by water content (Sharma et al., 2009). Since the seeds had been stored at various levels of humidity, they were taken out of cold storage and placed in Petri dishes that were then left open for $48 \mathrm{~h}$, to facilitate equilibration of water content prior to dehulling. The water content of the seeds was low, as they had previously been dried slightly to favour long-term storage: about 5.5-6.0\% (mean moisture $5.7 \%$ ) and sufficiently uniform (standard deviation $0.7 \%$ ) to permit a comparison of hullability.

A conical divider was used to produce 4 identical subsamples of approximately $15 \mathrm{~g}$ from the primary sample. Three replicates were used in the dehulling test; the 4th was used to measure water content. Employing a method determined by a previous study (Dauguet et al., 2015), the weighed samples were passed 3 times through the laboratory dehulling equipment, a Techmachine, at 2000 revolutions per minute (rpm). This is equivalent to limited or moderate dehulling in an industrial dehulling process which would result in $10 \%$ hull extraction, whereas $15 \%$ hull removal is current practice in industry.

After sorting using laboratory sorting equipment, the various fractions (kernels, whole seeds, fines and hulls) were weighed (to the nearest $0.01 \mathrm{~g}$ ). The percentage of extracted hulls was taken from the average of 3 replicates. Water content was assessed from the difference in seed weight before and after $15 \mathrm{~h}$ in an oven at $103^{\circ} \mathrm{C}$ (NF V03-909).

Hullability also was measured only for 2 varieties in each trial, except for the trials with a wider range of varieties studied ( 2 or 3 trials each year in each maturity group) where hullability was measured for each cultivar.

\subsection{Statistical analyses}

Data were analysed using analysis of variance (ANOVA). F-test and differences were evaluated via the StudentNewman-Keuls Test (software SAS 9.4). The coefficients of determination, and associated probability (Student) were also established using SAS software. Shapiro-Wilk tests were performed to check the normality of the residuals; homoscedasticity was verified visually.

\subsection{Calculation of the protein content in sunflower meal post-dehulling}

Given the defined quality characteristics of sunflower seeds (protein content, hullability), we developed a formula to estimate for each sample the protein content of the dehulled meal expressed as a percentage of raw matter (RM). In this way, we were able to assess the potential of a particular variety to produce meal of the required quality. This formula is based on measured values: initial seed protein content and the degree of hullability (percentage of extracted hulls), as well as assumptions regarding oil and moisture content of the meal, and the protein, oil and moisture content of the sunflower hulls. These assumptions were based on a yearly study of meal quality in the French crushing industry (Terres Inovia's unpublished results from a particular factory) and from an online database on feedstuffs (Feedipedia ${ }^{1}$ ) for parameters on hulls.

Assumptions:

$A=$ Oil content in meal in raw matter $(\mathrm{RM})=1.2 \%$

$B=$ Moisture content in meal $=11.5 \%$

$C=$ Protein content in hulls in $\mathrm{RM}=6 \%$

Moisture content in hulls $=10 \%$

Oil content in hulls in $\mathrm{RM}=2 \%$

$X=$ mass of removed hulls $(\mathrm{g} / 100 \mathrm{~g}$ seeds)

Formulae:

$D=$ Defatted Dry Matter (DDM) of seeds

$=1-($ moisture content of seeds $)-($ oil content of seeds on NMR)

$E=$ Protein content of seeds $(\% \mathrm{DDM})=$ protein content

of seeds $(\% \mathrm{DM}) /(1$ - oil content of seeds $(\% \mathrm{DM}))$

$F=$ Defatted Dry matter of the hulls

$=1-($ moisture content of hulls $)-($ oil content of hulls $)$

$=88 \%$

$G=$ Protein content of non-dehulled meal (\% RM)

$=E \times(1-A-B) \times\left(\frac{D}{1-A-B}\right)$

$H=$ Protein content of extracted hulls $(\% \mathrm{RM})=X \times C$

$I=$ Protein content of dehulled meal $(\% \mathrm{RM})$

$=\frac{G-H}{D-X \times F}(1-A-B)$

\section{Results and discussion}

\subsection{Analysis of variance}

The results were aggregated by maturity group and by year (Tabs. 2 and 3). Here, we assessed the influence of location and cultivar on the seed characteristics in 8 trials.

ANOVA were performed on the parameters studied using location and cultivar as explicative factors (Tabs. 2 and 3).

\footnotetext{
${ }^{1}$ Feedipedia, open access information system on animal feed resources, by INRA, CIRAD and FAO. Availlable at: www.feedipedia. org (checked on 3 December 2015).
} 
Table 2. Results for the Early group cultivars grown in eight trial locations (mean by cultivar, t comparison tests at 5\% and levels of significance of ANOVA of seed components).

\begin{tabular}{|c|c|c|c|c|c|c|c|c|c|c|}
\hline Year & \multicolumn{2}{|c|}{ Factor } & $\begin{array}{l}\text { Oil content } \\
\quad(\% \text { at } \\
\text { marketing } \\
\text { standards })\end{array}$ & $\begin{array}{c}\text { Thousand } \\
\text { seeds } \\
\text { weight } \\
\text { (g DM) }\end{array}$ & $\begin{array}{c}\text { Protein } \\
\text { content } \\
(\% \mathrm{DDM})\end{array}$ & $\begin{array}{l}\text { Protein } \\
\text { content } \\
(\% \mathrm{DM})\end{array}$ & $\begin{array}{c}\text { Crude } \\
\text { fibre } \\
(\% \mathrm{DDM})\end{array}$ & $\begin{array}{c}\text { Crude } \\
\text { fibre } \\
(\% \mathrm{DM})\end{array}$ & $\begin{array}{l}\text { Hullability } \\
\text { (\% extracted } \\
\text { hulls) }\end{array}$ & $\begin{array}{c}\text { Calculated } \\
\text { protein } \\
\text { content in } \\
\text { dehulled } \\
\text { meal } \\
(\% \mathrm{RM})\end{array}$ \\
\hline \multirow{7}{*}{2012} & \multirow{5}{*}{ Cultivar } & ES Biba & $46.1(\mathrm{~B})$ & $42.4(\mathrm{BC})$ & $34.5(\mathrm{~A})$ & $16.7(\mathrm{~B})$ & & & & \\
\hline & & Vellox & 47.9 (A) & 39.6 (C) & 36.2 (A) & 16.8 (B) & 28.3 (B) & 13.5 (B) & 11.0 (B) & 38.9 (A) \\
\hline & & Extrasol & 45.4 (B) & $45.4(\mathrm{AB})$ & $35.5(\mathrm{~A})$ & $17.4(\mathrm{~B})$ & 30.3 (A) & $15.0(\mathrm{~A})$ & $15.5(\mathrm{~A})$ & 41.5 (A) \\
\hline & & ES Balistic & $42.9(\mathrm{C})$ & 46.3 (A) & 35.9 (A) & $18.6(\mathrm{~A})$ & & & & \\
\hline & & ES Ethic & 46.0 (B) & $42.4(\mathrm{BC})$ & 34.5 (A) & $16.7(\mathrm{~B})$ & & & & \\
\hline & \multirow{2}{*}{$\begin{array}{c}\text { Level } \\
\text { of significance }\end{array}$} & Location & $* * *$ & $* * *$ & $* * *$ & $* * *$ & $* *$ & $* *$ & $\overline{\mathrm{NS}}$ & $\mathrm{NS}$ \\
\hline & & Cultivar & $* * *$ & $* * *$ & NS & $* * *$ & $* * *$ & $* * *$ & $* *$ & NS \\
\hline \multirow{8}{*}{2013} & \multirow{6}{*}{ Cultivar } & ES Biba & $48.1(\mathrm{C})$ & $49.7(\mathrm{C})$ & $32.4(\mathrm{AB})$ & $14.9(\mathrm{AB})$ & & & & \\
\hline & & Vellox & $52.3(\mathrm{~A})$ & $50.2(\mathrm{C})$ & $33.3(\mathrm{~A})$ & 13.8 (B) & & & & \\
\hline & & Extrasol & 47.7 (C) & $57.9(\mathrm{~A})$ & 33.5 (A) & $15.6(\mathrm{~A})$ & & & & \\
\hline & & SY Valeo & $48.2(\mathrm{C})$ & $50.4(\mathrm{C})$ & $31.3(\mathrm{AB})$ & 14.4 (B) & $35.5(\mathrm{~A})$ & $16.6(\mathrm{~A})$ & $10.2(\mathrm{~A})$ & 33.1 (A) \\
\hline & & ES Violetta & 47.7 (C) & $55.6(\mathrm{AB})$ & 30.9 (B) & 14.3 (B) & & & & \\
\hline & & Fydgi & 50.7 (B) & $52.1(\mathrm{BC})$ & $32.9(\mathrm{AB})$ & $14.2(\mathrm{~B})$ & $35.2(\mathrm{~A})$ & 15.3 (B) & $9.6(\mathrm{~A})$ & 34.7 (A) \\
\hline & \multirow{2}{*}{$\begin{array}{c}\text { Level } \\
\text { of significance }\end{array}$} & Location & $* * *$ & $* * *$ & $* *$ & $* *$ & NS & NS & $*$ & NS \\
\hline & & Cultivar & $* * *$ & $* * *$ & $* *$ & $* *$ & NS & $*$ & NS & NS \\
\hline
\end{tabular}

NS: non-significant; $* P<0.05 ; * * P<0.01 ; * * * P<0.001$.

Means per year within a column followed by the same letter are not significantly different $(P<0.05)$.

Table 3. Results for the ME/ML group cultivars grown in eight trial locations (means by cultivar and levels of significance of ANOVA of seed components).

\begin{tabular}{|c|c|c|c|c|c|c|c|c|c|c|}
\hline Year & \multicolumn{2}{|c|}{ Factor } & $\begin{array}{l}\text { Oil content } \\
\quad(\% \text { at } \\
\text { marketing } \\
\text { standards })\end{array}$ & $\begin{array}{l}\text { Thousand } \\
\text { seeds } \\
\text { weight } \\
\text { (g DM) }\end{array}$ & $\begin{array}{l}\text { Protein } \\
\text { content } \\
(\% \mathrm{DDM})\end{array}$ & $\begin{array}{l}\text { Protein } \\
\text { content } \\
(\% \mathrm{DM})\end{array}$ & $\begin{array}{c}\text { Crude } \\
\text { fibre } \\
(\% \mathrm{DDM})\end{array}$ & $\begin{array}{l}\text { Crude } \\
\text { fibre } \\
(\% \mathrm{DM})\end{array}$ & $\begin{array}{c}\text { Hullability } \\
\text { (\% extracted } \\
\text { hulls) }\end{array}$ & $\begin{array}{c}\text { Calculated } \\
\text { protein } \\
\text { content of } \\
\text { dehulled } \\
\text { meal } \\
(\% \mathrm{RM})\end{array}$ \\
\hline \multirow{7}{*}{2012} & \multirow{5}{*}{ Cultivar } & NK Kondi & $44.9(\mathrm{~A})$ & $41.1(\mathrm{~B})$ & $35.3(\mathrm{~A})$ & $17.5(\mathrm{C})$ & & & & \\
\hline & & Kapllan & 44.9 (A) & $42.7(\mathrm{AB})$ & 36.1 (A) & $17.9(\mathrm{BC})$ & & & & \\
\hline & & Extrasol & $43.6(\mathrm{AB})$ & $46.0(\mathrm{~A})$ & 36.7 (A) & $18.7(\mathrm{AB})$ & 29.1 (A) & 14.8 (B) & $16.8(\mathrm{~A})$ & 43.7 (A) \\
\hline & & DKF3333 & $43.2(\mathrm{~B})$ & $45.8(\mathrm{~A})$ & 36.1 (A) & $18.6(\mathrm{AB})$ & $30.0(\mathrm{~A})$ & $15.4(\mathrm{~A})$ & $15.3(\mathrm{~A})$ & $41.4(\mathrm{~A})$ \\
\hline & & LG5656HO & 42.3 (B) & $44.1(\mathrm{AB})$ & $36.3(\mathrm{~A})$ & $19.0(\mathrm{~A})$ & & & & \\
\hline & \multirow{2}{*}{$\begin{array}{c}\text { Level } \\
\text { of significance }\end{array}$} & Location & $* * *$ & $* * *$ & $* * *$ & $* * *$ & $* *$ & $* *$ & $* *$ & NS \\
\hline & & Cultivar & $* * *$ & $*$ & NS & $* *$ & NS & $*$ & NS & NS \\
\hline \multirow{9}{*}{2013} & \multirow{7}{*}{ Cultivar } & NK Kondi & $47.9(\mathrm{~A})$ & 49.1 (D) & $35.5(\mathrm{C})$ & $16.4(\mathrm{C})$ & $36.8(\mathrm{~A})$ & $17.4(\mathrm{~A})$ & 9.7 (B) & 37.3 (B) \\
\hline & & Kapllan & $48.2(\mathrm{~A})$ & $52.4(\mathrm{CD})$ & $38.0(\mathrm{AB})$ & 17.5 (B) & & & & \\
\hline & & Extrasol & 46.6 (B) & $56.3(\mathrm{~B})$ & $37.2(\mathrm{ABC})$ & $17.8(\mathrm{AB})$ & & & & \\
\hline & & DKF3333 & 46.9 (B) & $51.0(\mathrm{CD})$ & $37.7(\mathrm{ABC})$ & $17.9(\mathrm{AB})$ & & & & \\
\hline & & LG5656HO & $44.5(\mathrm{C})$ & $49.8(\mathrm{CD})$ & $37.4(\mathrm{ABC})$ & $18.7(\mathrm{~A})$ & & & & \\
\hline & & DOUGLLAS & $47.6(\mathrm{~A})$ & $60.1(\mathrm{~A})$ & $39.0(\mathrm{~A})$ & $18.0(\mathrm{AB})$ & & & & \\
\hline & & $\begin{array}{c}\text { ES TEKTONIC } \\
\text { CL }\end{array}$ & 46.0 (B) & $53.7(\mathrm{BC})$ & $36.2(\mathrm{BC})$ & $17.6(\mathrm{~B})$ & $36.1(\mathrm{~A})$ & $17.9(\mathrm{~A})$ & $14.4(\mathrm{~A})$ & $41.8(\mathrm{~A})$ \\
\hline & \multirow{2}{*}{$\begin{array}{c}\text { Level } \\
\text { of significance }\end{array}$} & Location & $* * *$ & $* * *$ & $* * *$ & $* * *$ & $*$ & $* *$ & * & * \\
\hline & & Cultivar & $* * *$ & $* * *$ & $* *$ & $* * *$ & NS & NS & $* * *$ & $* *$ \\
\hline
\end{tabular}

NS: non-significant; $* P<0.05 ; * * P<0.01 ; * * * P<0.001$.

Means within a column followed by the same letter are not significantly different $(P<0.05)$. 


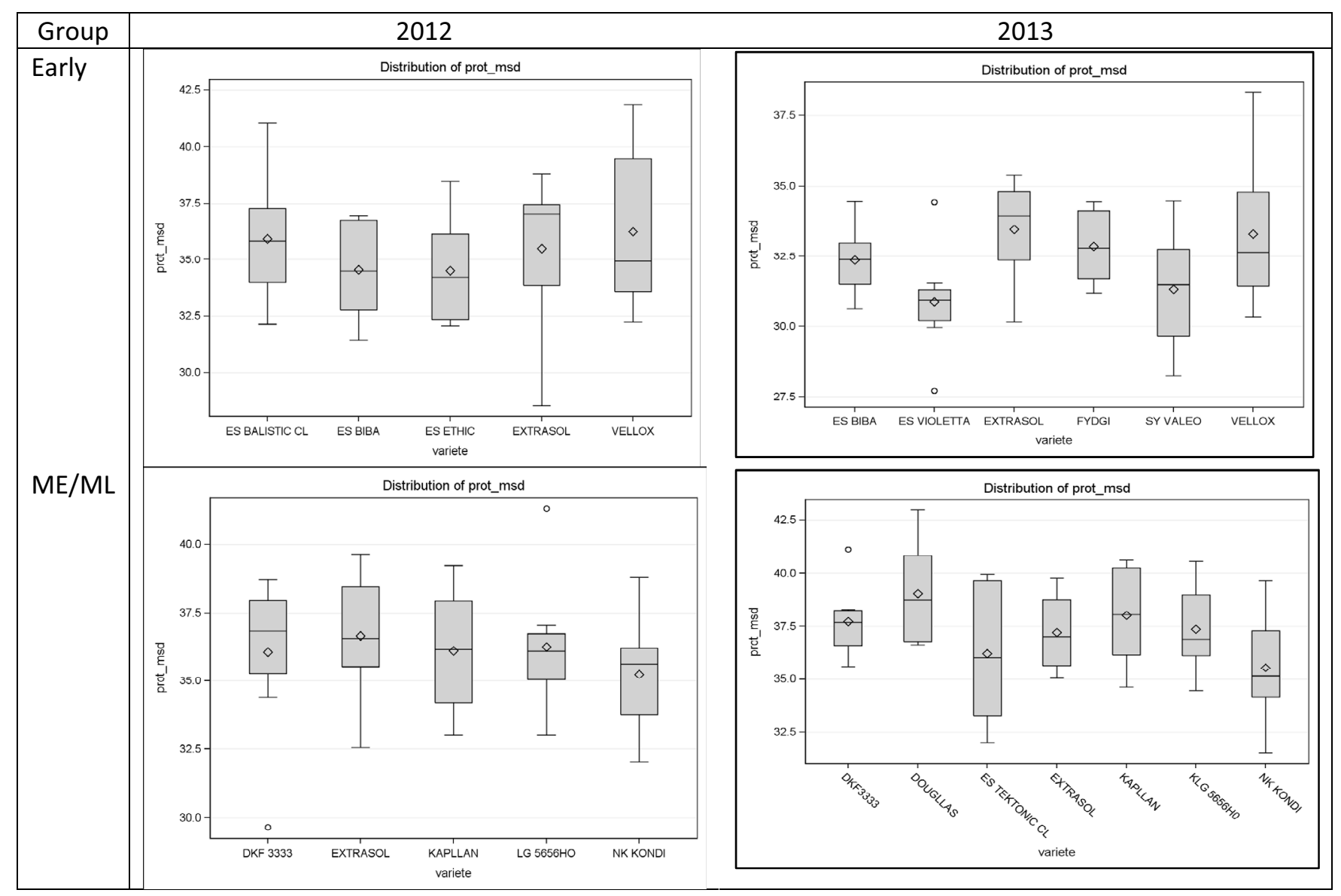

Fig. 2. Boxplots of cultivar effect on protein content (\%DDM) showing the median (line in the middle), mean (diamond), interquartile range (box) and total range (whiskers) not including atypical values (circle symbols, where they exist).

The impact of location was significant, except on hullability and crude fibre content in the early group and for the calculated protein content of the dehulled meal. This impact might be attributable to different meteorological and soil conditions affecting plant growth.

Cultivar was the principal factor affecting oil content, seed size (TSW) and percentage protein of DM. It did not however systematically affect the protein content of DDM: the variability for each variety was high (Fig. 2). Significant differences between varieties for protein content as a percentage of DDM were observed only in 2013: ES Violetta was significantly lower than Extrasol and Vellox (30.9\% versus 33.5 and 33.3\%) within the early group. Within the ME/ML group, NK Kondi and ES Tektonic had significantly lower protein contents than Dougllas (35.5\% and $36.2 \%$ versus 39\%). For this parameter, in 2012 the differences between locations were greater than the differences between cultivars.

For hullability, Vellox was significantly more difficult to dehull than Extrasol in 2012 (11\% extracted hulls versus 15.5), and NK Kondi had also a lower hullability than Es Tektonic in 2013 (9.7\% extracted hulls versus $14.4 \%)$. However, there was no significant difference between SY Valeo and Fydgi in 2013, or between Extrasol and DKF3333 in 2012, as the differences between locations were high (Fig. 3).
It is difficult to conclude from the results for crude fibre content. Crude fibre associated with higher hull content in seeds could be a favourable factor for hullability. For example, Extrasol had significantly higher crude fibre content (on DDM and on DM) than Vellox, which could be related to a better hullability, but, ES Tektonic showed better hullability than NK Kondi, although these two varieties had comparable crude fibre contents. This led to a conclusion that crude fibre content was not the unique factor affecting hullability. Seed size, hull structure and the phenomenon of adherence were probably important also.

The final aspect, the right hand column in Tables 2 and 3, a calculation of the potential protein content in meal that would be obtained after dehulling, based on protein content of the seeds and hullability, did not show significant genetic differences, except between NK Kondi and ES Tektonic, as the second had a better hullability and gave a richer meal. This parameter suggests that the protein content of meal could be quite high, above the standard level in high-protein meal (36\%), since for some cultivars in some years it exceeded $40 \%$. It was only in the early group in 2013 that the protein content was low for all the varieties, and hullability was moderate; so the calculated protein richness in the meal was less than the standard $36 \%$. This highlighted the importance of initial protein content in seeds in the production of good quality meal. 


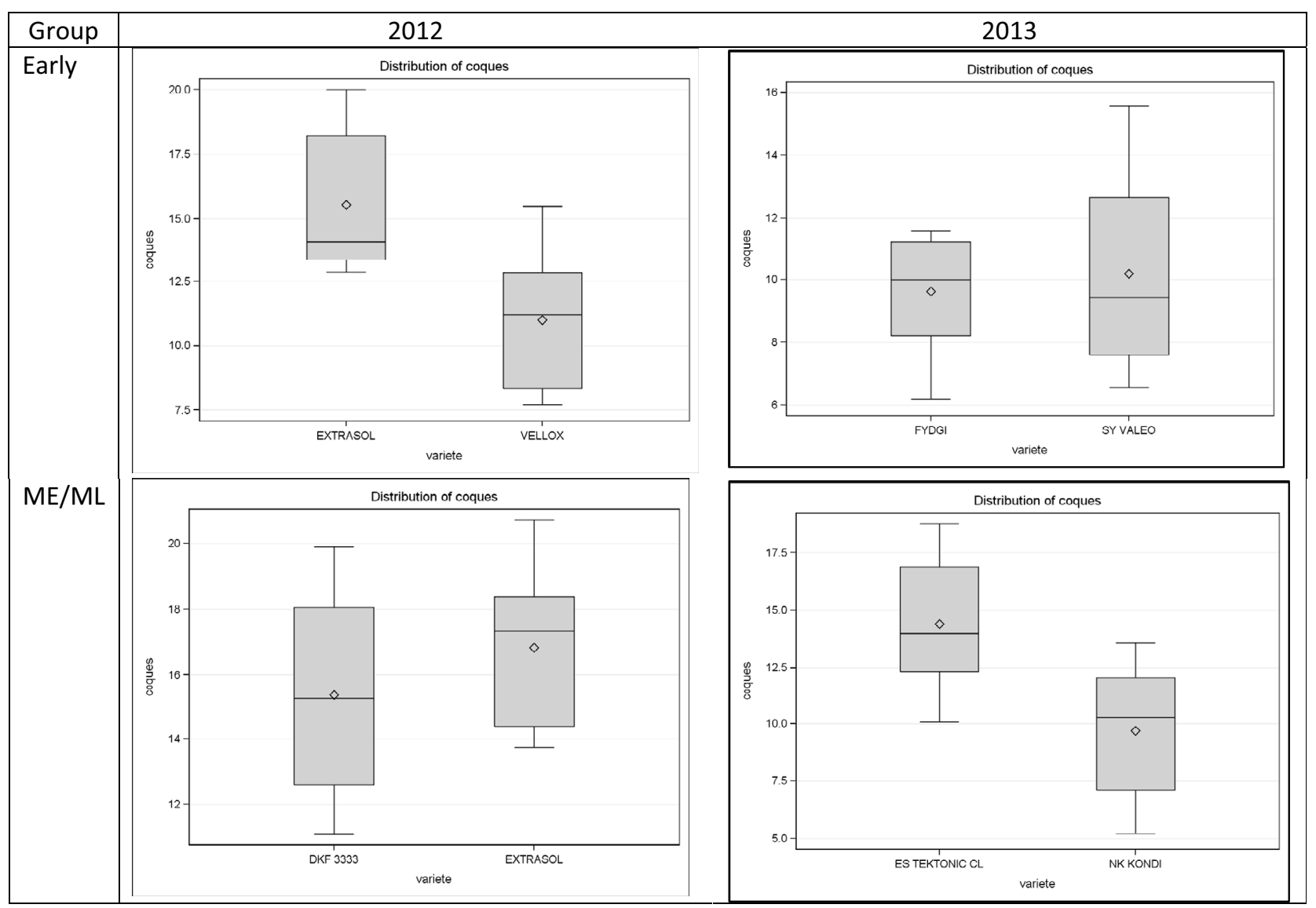

Fig. 3. Boxplots of cultivar effect on hullability ( $\%$ of extracted hulls) showing the median (line in the middle), mean (diamond), interquartile range (box) and total range (whiskers).

\subsection{Year effect}

Some trial locations and cultivars were constant in both years, which enabled the evaluation of the effect of year (including the climatic effect) (Tab. 4):

- for the early group, 4 locations (Antoigné, Levroux, Vibrac and Maslacq) and 3 varieties (ES Biba, Vellox, Extrasol),

- for the ME/ML group, 3 locations (Duras, Tané, Lévignac) and 5 varieties (NK Kondi, Kapllan, Extrasol, DKF3333, LG5656HO).

It was rainier and less sunny in 2012 than in 2013. During 2013, water stress occurred after flowering, which led to lower yields in the South and West of France and in the country as a whole (respectively $2.38 \mathrm{t} /$ ha in 2012, and $2.14 \mathrm{t} /$ ha in 2013, according to public statistics). In the studied, this trend was observed for the early cultivar group, but it was not substantial (yield $20123.8 \mathrm{t} / \mathrm{ha}$ and yield $20133.57 \mathrm{t} / \mathrm{ha}$ ); while the situation was the opposite for the ME/ML cultivar group with better yields in 2012 (3.66 t/ha) than in 2013 (3.42 t/ha). This is due to the fact that the varietal evaluation trials were grown in more optimal conditions than normal farmers' fields, and therefore were not representative of national sunflower production. The climatic effect influenced the oil content and seed size (TSW), higher in 2013 than in 2012, and percentage protein content of DM, higher in 2012, which was a consequence of lower oil content in 2012. For the percentage protein content of DDM, a significant difference was observed only in the early cultivar group, with higher levels observed in 2012 than in 2013.

\subsection{The wider range of varieties}

Each year, 15 cultivars were sampled and analysed in 2 (2012) or 3 (2013) locations for each maturity group, to obtain some idea of the diversity of cultivar profiles for protein content as a percentage of DDM and their hullability, and for their potential to produce good quality meal.

This larger panel of cultivars made it possible to assess the potential variability of the protein content in dehulled meals. The range for the calculated protein content of dehulled meal (Tab. 5) is large, with 10 percentage points between the poorest and the best cultivars within ME/ML group in 2013 (for other maturity groups and years, the range was 7 to 9 points; the results are not presented here).

Location and cultivar effects were significant for all parameters in Table 5: oil content, seed size (TSW), percentage protein content of DDM, hullability and the calculated protein content of the dehulled meal. We were able, therefore, to distinguish varieties with contrasting characteristics, not only for oil content, but also concerning parameters that affect the possibility of obtaining meal with high protein content.

Cultivars LG5656HO and Dougllas had significantly higher calculated protein content in their dehulled meal (44.4\% and $42.5 \%$ ) than cultivars LG5687HA and SY EDENIS 
Table 4. Analysis of variance for year, location and cultivar effects on seed characteristics (means, $t$ comparison tests at $5 \%$ and levels of significance).

\begin{tabular}{|c|c|c|c|c|c|c|c|}
\hline & ors & $N$ & $\begin{array}{c}\text { Oil }) \\
\text { content } \\
(\% \text { at } \\
\text { marketing } \\
\text { standards }\end{array}$ & $\begin{array}{c}\text { TSW } \\
\text { (g DM) }\end{array}$ & $\begin{array}{c}\text { Yield (t/ha at) } \\
\text { marketing } \\
\text { standards }\end{array}$ & $\begin{array}{c}\text { Protein } \\
\text { content } \\
(\% \text { DDM })\end{array}$ & $\begin{array}{l}\text { Protein } \\
\text { content } \\
(\% \mathrm{DM})\end{array}$ \\
\hline \multirow{5}{*}{ Early } & 2012 & 12 & $47.5(\mathrm{~B})$ & $45.4(\mathrm{~B})$ & $3.80(\mathrm{~A})$ & $35.8(\mathrm{~A})$ & $16.7(\mathrm{~A})$ \\
\hline & 2013 & 12 & $49.3(\mathrm{~A})$ & $55.3(\mathrm{~A})$ & $3.57(\mathrm{~A})$ & $33.3(\mathrm{~B})$ & 14.9 (B) \\
\hline & Year & & * & $* * *$ & NS & * & ** \\
\hline & Location & & NS & NS & NS & $* *$ & ** \\
\hline & Cultivar & & $* *$ & * & NS & NS & $\mathrm{NS}$ \\
\hline \multirow{5}{*}{ ME/ML } & 2012 & 15 & $44.3(\mathrm{~B})$ & $41.6(\mathrm{~B})$ & $3.42(\mathrm{~B})$ & $37.4(\mathrm{~A})$ & $18.8(\mathrm{~A})$ \\
\hline & 2013 & 15 & $48.0(\mathrm{~A})$ & $47.5(\mathrm{~A})$ & $3.66(\mathrm{~A})$ & $37.2(\mathrm{~A})$ & $17.2(\mathrm{~B})$ \\
\hline & Year & & *** & $* *$ & * & NS & *** \\
\hline & Location & & $* *$ & NS & * & NS & NS \\
\hline & Cultivar & & ** & NS & *** & $\mathrm{NS}$ & ** \\
\hline
\end{tabular}

NS: non-significant; $* P<0.05 ; * * P<0.01 ; * * * P<0.001$.

Means within a column followed by the same letter are not significantly different $(P<0.05)$ with $t$ test.

Table 5. Analysis of variance for seed components from 15 ME/ML group cultivars, grown in 3 locations in 2013 (means and level of significance of ANOVA on seed components).

\begin{tabular}{cccccc}
\hline Cultivar & $\begin{array}{c}\text { Oil content } \\
\text { \% at marketing } \\
\text { standards })\end{array}$ & $\begin{array}{c}\text { TSW } \\
(\mathrm{g} \mathrm{DM})\end{array}$ & $\begin{array}{c}\text { Protein } \\
\text { content } \\
(\% \mathrm{DDM})\end{array}$ & $\begin{array}{c}\text { Hullability } \\
\text { \% extracted } \\
\text { hulls })\end{array}$ & $\begin{array}{c}\text { Calculated } \\
\text { protein } \\
\text { content of } \\
\text { dehulled meal }(\% \mathrm{RM})\end{array}$ \\
\hline CLLOSER & $49.7(\mathrm{~A})$ & $53.2(\mathrm{ABC})$ & $39.0(\mathrm{AB})$ & $7.3(\mathrm{CD})$ & $39.1(\mathrm{ABCD})$ \\
MEDDIA CS & $49.0(\mathrm{AB})$ & $47.1(\mathrm{C})$ & $41.3(\mathrm{~A})$ & $3.7(\mathrm{E})$ & $38.6(\mathrm{BCD})$ \\
KAPLLAN & $48.5(\mathrm{BC})$ & $53.1(\mathrm{ABC})$ & $38.9(\mathrm{AB})$ & $10.3(\mathrm{BC})$ & $41.5(\mathrm{ABC})$ \\
DOUGLLAS & $47.6(\mathrm{CD})$ & $61.3(\mathrm{~A})$ & $39.4(\mathrm{AB})$ & $11.0(\mathrm{~B})$ & $42.5(\mathrm{AB})$ \\
NK KONDI & $47.4(\mathrm{CD})$ & $51.3(\mathrm{BC})$ & $36.1(\mathrm{BC})$ & $9.5(\mathrm{BCD})$ & $37.4(\mathrm{BCD})$ \\
LG5687HO & $47.2(\mathrm{DE})$ & $48.0(\mathrm{C})$ & $35.6(\mathrm{BC})$ & $8.6(\mathrm{BCD})$ & $36.2(\mathrm{CD})$ \\
SY EXPLORER & $46.9(\mathrm{DEF})$ & $51.4(\mathrm{BC})$ & $36.9(\mathrm{ABC})$ & $9.8(\mathrm{BCD})$ & $38.5(\mathrm{BCD})$ \\
DKF3333 & $46.8(\mathrm{DEF})$ & $51.8(\mathrm{BC})$ & $38.3(\mathrm{AB})$ & $7.0(\mathrm{D})$ & $37.8(\mathrm{BCD})$ \\
LG5528 & $46.8(\mathrm{DEF})$ & $51.5(\mathrm{BC})$ & $38.4(\mathrm{AB})$ & $8.7(\mathrm{BCD})$ & $39.3(\mathrm{ABCD})$ \\
SY EDENIS & $46.6(\mathrm{DEF})$ & $50.8(\mathrm{BC})$ & $33.2(\mathrm{C})$ & $10.0(\mathrm{BCD})$ & $34.7(\mathrm{D})$ \\
EXTRASOL & $46.5(\mathrm{DEF})$ & $57.9(\mathrm{AB})$ & $38.5(\mathrm{AB})$ & $9.7(\mathrm{BCD})$ & $40.2(\mathrm{ABC})$ \\
ES AKUSTIC & $46.2(\mathrm{DEF})$ & $57.0(\mathrm{AB})$ & $39.2(\mathrm{AB})$ & $10.0(\mathrm{BCD})$ & $41.1(\mathrm{ABC})$ \\
LG5625 & $45.7(\mathrm{EF})$ & $55.4(\mathrm{ABC})$ & $35.0(\mathrm{BC})$ & $14.3(\mathrm{~A})$ & $39.9(\mathrm{ABCD})$ \\
ES TEKTONIC CL & $45.6(\mathrm{~F})$ & $54.6(\mathrm{ABC})$ & $37.0(\mathrm{ABC})$ & $13.5(\mathrm{~A})$ & $41.5(\mathrm{ABC})$ \\
LG5656HO & $44.4(\mathrm{G})$ & $50.8(\mathrm{BC})$ & $38.8(\mathrm{AB})$ & $14.7(\mathrm{~A})$ & $44.4(\mathrm{~A})$ \\
Cultivar effect & $* * *$ & $* * *$ & $* * *$ & $* * *$ & $* * *$ \\
Location effect & $* * *$ & $* * *$ & $* * *$ & $* * *$ & $* * *$ \\
\hline
\end{tabular}

NS: non-significant; $* P<0.05 ; * * P<0.01 ; * * * P<0.001$.

Means per cultivar within a column followed by the same letter are not significantly different $(P<0.05)$ with Student-Newman-Keuls comparison test.

(34.8\% and 34.9\%). However, for all other varieties, we could not draw a firm conclusion, as the differences concerning this parameter were not significant.

Thus, with this wider number of varieties, various combinations of seed characteristics were identified:

- Varieties with low or medium oil content, but high protein content (as a percentage of DDM) and good or medium hullability, giving a high protein meal (LG5656HO, ES TEKTONIC, Extrasol, ES Akustic).
- Some varieties with high oil content, high protein content (as a percentage of DDM) and medium hullability, giving a high protein meal (Dougllas, Kapllan).

- Some varieties with medium oil content, poor protein content (as a percentage of DDM) and medium hullability, giving a lower protein meal compared to other varieties (SY Edenis, LG5687HO).

- Some varieties with very high oil content, high protein content (as a percentage of DDM) but low or very low hullability, giving a medium protein meal (Clloser, Meddia CS). 
Table 6. Pearson correlation matrix concerning 2013 trials (first line Pearson correlation coefficient (R), second line number of samples).

\begin{tabular}{|c|c|c|c|c|c|c|c|}
\hline & TSW & $\begin{array}{l}\text { Protein content } \\
(\% \mathrm{DDM})\end{array}$ & $\begin{array}{l}\text { Protein content } \\
(\% \mathrm{DM})\end{array}$ & $\begin{array}{l}\text { Crude fibre } \\
(\% \mathrm{DDM})\end{array}$ & $\begin{array}{l}\text { Crude fibre } \\
\text { (\%DM) }\end{array}$ & $\%$ extracted hulls & $\begin{array}{c}\text { Calculated } \\
\text { protein content } \\
\text { of dehulled } \\
\text { meal (\% RM) }\end{array}$ \\
\hline \multirow{2}{*}{ Oil content } & $-0.38452 * * *$ & $-0.20423^{*}$ & $-0.59629 * * *$ & $-0.17711 N S$ & $-0.78159 * * *$ & $-0.59706^{* * *}$ & $-0.51507 * * *$ \\
\hline & 157 & 157 & 157 & 32 & 32 & 107 & 107 \\
\hline \multirow{2}{*}{ TSW } & & $0.08842 N S$ & $0.23748 * *$ & $0.33684 N S$ & $0.31760 N S$ & $0.40733 * * *$ & $0.39198 * * *$ \\
\hline & & 157 & 157 & 32 & 32 & 107 & 107 \\
\hline Protein content & & & $0.90667 * * *$ & $0.08418 N S$ & $0.43585^{*}$ & $-0.28675^{* *}$ & $0.76529 * * *$ \\
\hline (\%DDM) & & & 157 & 32 & 32 & 107 & 107 \\
\hline Protein content & & & & $0.13256 N S$ & $0.63598 * * *$ & $-0.00416 N S$ & $0.85291 * * *$ \\
\hline$(\% \mathrm{DM})$ & & & & 32 & 32 & 107 & 107 \\
\hline Crude fibre & & & & & $0.72126 * * *$ & $0.35681 *$ & $0.25643 N S$ \\
\hline$(\% \mathrm{DDM})$ & & & & & 32 & 31 & 31 \\
\hline Crude fibre & & & & & & $0.70678 * * *$ & $0.64457 * * *$ \\
\hline$(\% \mathrm{DM})$ & & & & & & 31 & 31 \\
\hline$\%$ extracted & & & & & & & $0.38716 * * *$ \\
\hline hulls & & & & & & & 107 \\
\hline
\end{tabular}

NS: non-significant; $* P<0.05 ; * * P<0.01 ; * * * P<0.001$.

Turning to the economic aspect, some varieties would be more profitable than others. The outlines of an economic approach can be suggested, but would require further development if sunflower ideotypes are to be determined. Using 2015 market data (oil price of $750 € / \mathrm{t}, 36 \%$ protein meal at $260 € / \mathrm{t}$ and hulls at $80 € / \mathrm{t}$ ), and by calculating the rate of hull removal necessary to produce a $36 \%$ protein-content meal (based on the formula presented in Sect. 2.5), we calculated the likely achievable income of some cultivars. Oil content was the main factor affecting income, with percentage protein content of DDM as the second factor (using high protein content seeds, a lower percentage of hulls can be removed to produce $36 \%$ protein meal, the quantity of which is therefore greater). The cultivars that would produce the highest expected incomes belonged to the varietal groups combining high or very high oil contents and high protein contents: Meddia CS, Clloser, Kapplan, Dougllas (494 to $505 €$ /ton of processed seeds). The lowest incomes were obtained for cultivars displaying low/medium oil contents: LG5625, SY Edenis, LG5656HO and ES Tektonic (472 to $477 € /$ ton of processed seeds).

\subsection{Crude fibre content analysis could replace hullability tests?}

In 2013, hullability (percentage of extracted hulls) was significantly correlated with: oil content, thousand seeds weight, percentage protein content of DDM, percentage crude fibre content of DDM and percentage crude fibre content of DM (Tab. 6). Only percentage protein content of DM was not correlated. The closest correlation was with crude fibre content in DM (Fig. 4). The results of the 2012 correlation matrix gave the same conclusions.

This could be explained by the fact that the percentage cellulose content of dry matter was both highly correlated with the percentage cellulose content of DDM (the richer is the whole seed in fibre, the richer also in fibre is the defatted fraction of the seed) and oil content (the richer is the seed in oil,

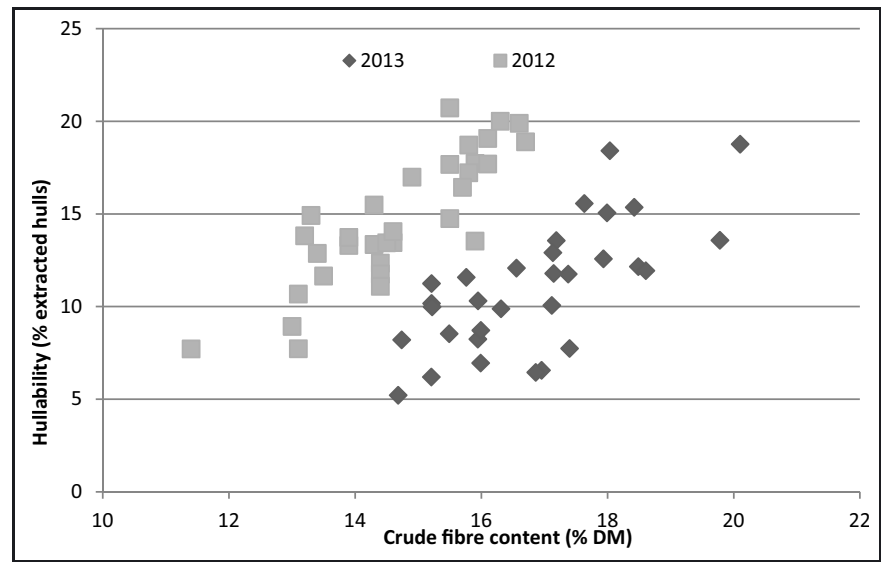

Fig. 4. Relationship between on hullability (\% of extracted hulls) and crude fibre content of sunflower seeds.

the greater is the reduction of the defatted fraction, which lowers the proportion of cellulose). Previous studies had shown on the one hand that hullability is significantly and negatively correlated with the seed oil content (Dauguet et al., 2015; Denis et al., 1994); and on the other, since the crude fibre is concentrated mainly in the hulls, that hullability is strongly and positively correlated with the seed hull content (not assessed in this present study, but demonstrated by Baldini et al., 1994; Denis et al., 1994; Nel, 2001). Thus, the crude fibre content as a percentage of DM incorporates both the effect of fibre content as a percentage of DDM, and the effect of oil content on hullability.

An analysis of covariance was conducted, testing the effects of crude fibre content expressed as a percentage of DM, year and the interaction "Crude fibre DM $\times$ Year" on the extracted hull rates (Tab. 7). It showed a year effect, i.e. a different intercept but, no interaction effect (similar slopes).

The crude fibre content analyses were performed on: DKF3333, Vellox and Extrasol in 2012 and NK Kondi, ES Tektonic, Fydgi and SY Valeo in 2013. However, the climatic 


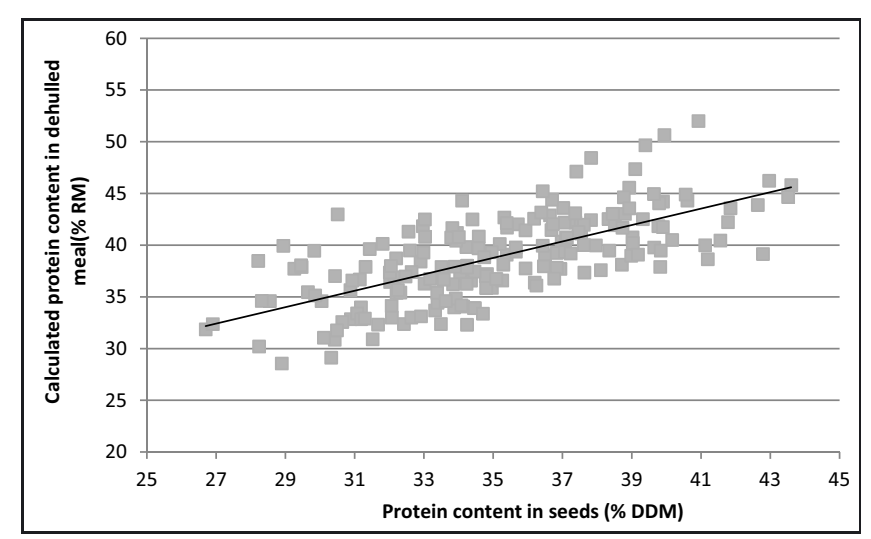

Fig. 5. Relationship between calculated protein content in dehulled meal (\% RM) and protein content of sunflower seeds (\% DDM).

Table 7. Analysis of covariance results for the percentage of extracted hulls variable (2012 and 2013 data).

\begin{tabular}{cccc}
\hline Parameter & $\begin{array}{c}\text { Estimated } \\
\text { value }\end{array}$ & $\begin{array}{c}\text { Standard } \\
\text { error }\end{array}$ & $\operatorname{Pr}>|t|$ \\
\hline Intercept & -22.85 & 3.57 & $<0.0001$ \\
Crude fibre content & 2.01 & 0.21 & $<0.0001$ \\
Year 2012 & 8.04 & 0.72 & $<0.0001$ \\
Year 2013 (reference) & 0 & & \\
\hline \multicolumn{4}{c}{$R^{2}$ model =0.69 } \\
\hline
\end{tabular}

context was probably the most impacting parameter since hullability was lower overall in 2013 compared to 2012 (Tabs. 2 and 3), which may be linked to a higher oil content in 2013 compared to 2012 (Tab. 4).

Thus, if significant advances are made in the near future in the development of rapid non-destructive analysis methods, determining the crude fibre content as a percentage of DM would be an appropriate way to assess the hullability of varieties in sunflower breeding programmes. An annual calibration does, however, appear necessary.

\subsection{Predicting the potential of a variety for producing a meal with high protein content?}

It appears that protein content of dehulled sunflower meal (calculated data for each sample from the seed protein content and rate of extracted hulls by the method outlined in Sect. 2.5) was most closely correlated with seed protein content as a percentage of DDM ( $p<0.0001$ and $R^{2}=0.59$, see Tab. 6 for 2013 data) and much less related to the rate of hulls extracted ( $p<0.0001, R^{2}=0.15$, see Tab. 6 for 2013 data). From this, it may be concluded that the initial seed protein content is of paramount importance for obtaining high protein meals.

Taking all the data for 2012 and 2013 together, we obtained equation (1).

Equation (1): Relationship between protein content of dehulled meal and protein content as a \% of DM (2012 and 2013 data, Fig. 5)

Prot-dehulled-meal $=18.198+0.6391 \times($ protein content DDM $)$

$$
\left(R^{2}=0.43\right)
$$

Adding crude fibre content to the model could improve the equation, as this parameter was correlated with hullability. Taking into account the year effect, as shown in Section 3.4, could further improve the predictive model.

Equation (2): Protein content of dehulled meal (\% RM) as a function of protein content DM and crude fibre content DM, and including year effect (2012 and 2013 data).

$$
\begin{aligned}
\text { 2013: Prot-dehulled-meal }= & -26.22+1.12 \\
& \times(\text { protein content DDM })+1.48 \\
& \times(\text { crude fibre content DM }) \\
\text { 2012: Prot-dehulled-meal }= & -20.73+1.12 \\
& \times(\text { protein content DDM })+1.48 \\
& \times(\text { crude fibre content DM })
\end{aligned}
$$

Significance: General model $p<0.0001$; intercept $p<$ 0.0001 ; protein content DDM $p<0,0001$; crude fibre content DM $p<0.0001$; year effect $p<0.0001$.

$R^{2}($ model $)=0.86 ;$ partial $R^{2}($ protein content $\mathrm{DDM})=$ 0.66 ; partial $R^{2}$ (crude fibre content $\left.\mathrm{DM}\right)=0.16$; partial $R^{2}$ $($ year effect $)=0.05$.

A calibration of this equation (2) according year results in a more accurate estimate, and enables classification of varieties according to their capacity to produce meal with improved protein content after dehulling.

\section{Conclusion}

At present, sunflower breeding programmes do not take into account the characters of protein content and hullability. So if the crushing industry wishes to produce a high protein meal it would have to review the dehulling process. In this study, we identified sunflower varieties that combine both high oil and high protein content. The protein content of sunflower seeds proved to be the key characteristic determining the quality of sunflower meal; improvement by breeding would help to improve both meal quality and the profitability of the crushing process. Selection of varieties with particularly high oil contents could have a negative impact on hullability; it may be worthwhile checking this in order to avoid difficulties at crushing plants.

Results observed in this study proved that for selection of cultivars producing sunflower meal with more than $40 \%$ protein content is perfectly feasible without having to remove more than $13 \%$ of seed mass in hulls. This study also highlighted important environmental effects (year and location) on protein content and hullability; this indicates that cultivar selection alone is not sufficient to ensure the production of a precise quality target for the seeds, although it should reduce the risk of failing to deliver meal of a commercial standard and/or losing too much oil in the hulls extracted. The question remains open as to whether the stakeholders in sunflower oil mills would benefit from negotiating specifications with their suppliers to segregate crops that have strong potential for producing high protein meal. A framework for sharing the earnings attributable to seed protein content could be set up for farmers. Further technical and economic assessments are 
needed to comprehensively address these possibilities. Action on them could lead to the adoption of new breeding strategies and significant improvements in the quality of sunflower meal.

Acknowledgements. This work has been supported by Terres Univia, the French oil and protein inter-branch organisation.

\section{References}

Baldini M, Vannozzi GP, Cecco F, Macchia M, Bonari E, Benvenuti A. 1994. Genetic analysis of hullability in sunflower. Ind. Crops Prod. 3: 29-35.

Dauguet S, Fine F, Guillemain C, et al. 2015. Impact of pedoclimatic and agricultural conditions on sunflower sedes characteristics in relation to the dehulling process. OCL 22: $\mathrm{D} 402$.

Denis L, Vear F. 1996. Variation of hullability and other seed characteristics among sunflower lines and hybrids. Euphytica 87: 177187.

Denis L, Dominguez J, Baldini M, Vear F. 1994. Genetical studies of hullability in comparison with other sunflower seed characteristics. Euphytica 79: 29-38.
Evrard J, Burghart P, Carré P, et al. 1996. Improvement of sunflower dehulling ability an interdisciplinary approach. In: Proc. 14th Int. Sunfl. Conf., Beijing/Shenyang, China. Int. Sunfl. Assoc., Paris, France.

Nel AA. 2001. Determinants of sunflower seed quality for processing. Ph.D. Diss. Univ. of Pretoria, Pretoria, Republic of South Africa. Available at: http://upetd.up.ac.za/thesis/available/ etd-09012001-132144/ (verified 21 Aug. 2014).

Oraki H, Alahdadi I, Parhizkar khajani F. 2011. Influence of water deficit and genotype on protein, oil contents and some physical characteristics of sunflower seeds. Afr. J. Agric. Res. 6: 12461250.

Peyronnet C, Pressenda F, Quinsac A, Carré P. 2012. Impact du décorticage du tournesol sur la valeur nutritionnelle et l'intérêt économique des tourteaux en fabrication d'aliments composés. OCL 19: 341-346.

Sharma R, Sogi DS, Saxena DC. 2009. Dehulling performance and textural characteristics of unshelled and shelled sunflower (Helianthus annuus L. seeds. J. Food Eng. 92: 1-7.

Tostain S, Chervier P, Laulan A, Kermorgant T. 2012. Amélioration de l'autonomie énergétique et de l'impact environnemental d'une unité de trituration de tournesol par l'implantation conjointe d'un atelier de décorticage et d'une chaudière à coques. OCL 19: 332 340 .

Cite this article as: Sylvie Dauguet, Françoise Labalette, Frédéric Fine, Patrick Carré, André Merrien, Jean-Pierre Palleau. Genetic impact on protein content and hullability of sunflower seeds, and on the quality of sunflower meal. OCL 2016, 23(2) D205. 